\title{
Salvinia auriculata: Aquatic bioindicator studied by instrumental neutron activation analysis (INAA)
}

\author{
Daniel Crístian Ferreira Soares ${ }^{\mathrm{a}}$, Ester Figueiredo de Oliveira ${ }^{\mathrm{a}}$, Grácia Divina de Fátima \\ Silva $^{\mathrm{b}}$, Lucienir Pains Duarte ${ }^{\mathrm{b}}$, Vali Joana Pott ${ }^{\mathrm{c}}$, Sidney Augusto Vieira Filho ${ }^{\mathrm{d}, *}$ \\ ${ }^{a}$ Centro de Desenvolvimento da Tecnologia Nuclear (CDTN/CNEN), Avenida Antônio Carlos, 6627 Pampulha, CEP $30123-970$ Belo Horizonte, \\ Minas Gerais, Brazil \\ ${ }^{\mathrm{b}}$ Departamento de Química, ICEx, Núcleo de estudos de Plantas Medicinais (NEPLAM), Universidade Federal de Minas Gerais, \\ Avenida Antônio Carlos, 6627 Pampulha, 31270-901 Belo Horizonte, Minas Gerais, Brazil \\ ${ }^{\mathrm{c}}$ Empresa Brasileira de Agropecuária (EMBRAPA), BR 262 km 4, Caixa Postal 154, CEP $79002-970$ Campo Grande, Mato Grosso do Sul, Brazil \\ ${ }^{\mathrm{d}}$ Escola de Farmácia, DEFAR, Universidade Federal de Ouro Preto, Rua Costa Sena, 171, CEP 35400-000 Ouro Preto, Minas Gerais, Brazil
}

Received 7 August 2007; received in revised form 26 November 2007; accepted 30 November 2007

\begin{abstract}
Through instrumental neutron activation analysis (INAA) the elemental chemical composition of Salvinia auriculata and Ouro Preto city public water was determined. Elements $\mathrm{Ce}$, Th, $\mathrm{Cr}, \mathrm{Hf}, \mathrm{Sb}, \mathrm{Sc}, \mathrm{Rb}, \mathrm{Fe}, \mathrm{Zn}, \mathrm{Co}, \mathrm{Au}$, La and Br were quantified. High chromium concentration was determined in this plant. But, chromium was determined only in low concentrations in the water. The results indicate the great capacity of this plant to absorb and accumulate inorganic elements.
\end{abstract}

(C) 2007 Published by Elsevier Ltd.

Keywords: Aquatic macrophyte; Salvinia auriculata; Salvinaceae; INAA; Elementary analysis

\section{Introduction}

The bioremediation, phytoremediation, and biosorption processes act through both living and dead organic matter to extract organic and inorganic compounds from polluted soil and water. These procedures have been used since the 1970s (Litchfield, 2005). It was known for decades that bacteria, algae and aquatic plants can absorb certain heavy metals, but only recently has this information been applied to remove dangerous heavy metals from contaminated soil and water. Among the great variety of plants, lichens are used to track metals in the environment (Saiki et al., 1997; Vaz et al., 1995). These organisms have been also used to uptake and isolate heavy metals by absorption from water or soil followed by burning the organic material to obtain an inorganic residual material (Eccles, 1999). Other studies have been conducted to find plants and other microorgan-

\footnotetext{
*Corresponding author.

E-mail address: bibo@ef.ufop.br (S.A.V. Filho).
}

isms with potential capacity to remove heavy metals from soil and aqueous solutions.

Roots of some aquatic macrophytes have great ability to uptake and bioaccumulate elements, phosphates, nitrogen oxides and/or non-polar organic compounds from water or sediments (Garg and Chandra, 1990; Schneider and Rubio, 1999). For these reasons aquatic macrophytes also represent an excellent bioindicator of the quality of water and sediments (Klumpp et al., 2002; Srivastav et al., 1994). These plants can remove metals encountered in low concentrations from a public water supply in a few hours (Forno and Harley, 1979).

Salvinia auriculata (Salvinaceae) is a good example of aquatic macrophytes that present the ability to uptake elements and organic compounds from water and wastewater. S. auriculata has a common name of floating water moss or eared water moss. It is a free-floating aquatic plant lacking true roots, a rhizome with stele $\mathrm{U}$-shaped in cross section. Its leaves have green to brown colors, are oblongelliptic to nearly circular, with apex obtuse or retuse, base cordate or subcordate and larger ones $1.5-2.5 \mathrm{~cm}$ long. Its 
upper surface is densely provided with short to greatly elongated papillae, arranged in rows parallel to the main lateral veins and each of them develops at the apex in a group of 4 trichomes which are all joined at their ends (Stolze et al., 1983). S. auriculata is a fertile specie. It is dependent on spore production and overwintering for annual recurrence. Floating plants completely die during the winter months in low-temperature countries. New populations develop from wintered spores that, having lain dormant in the sediment, rise to the water surface and germinate during the warming temperatures of spring. The same cycle takes place in a wet-and-dry habitat.

The concentration of elements in an aquatic ecosystem is dependent on their mobility (Callender and Rice, 2000). This property is a function of many factors like adjacent soil composition, solubility in water and the interaction with sediment and soil components. The kind of interaction is directly dependent on reactions involving ionic charge, atomic ray, temperature, $\mathrm{pH}$, ligant types and others (Larcher, 2000).

The study of inorganic composition is very important since many elements participate directly in many plant metabolic processes (Pardeshi and Rajurkar, 1997). However, the detection of elements is difficult because of their very low concentrations in natural water, generally below $0.1 \%$.

In order to determine trace elements, various analytical methods have been developed (e.g. inductive coupled plasma-atomic emission spectroscopy, X-ray fluorescence, isotope dilution thermal ionization mass spectrometry, neutron activation analysis, and others), but each method has different limitations (e.g., sample preparation, sample dissolution, limited number of analyzed elements). Instrumental neutron activation analysis (INAA) has excellent sensitivity and rapidity and the advantage of being largely insensitive to matrix effects; it also has precision and can execute simultaneous multi-element determinations (International Atomic Energy Agency, 2001). These INAA characteristics have been widely applied, mainly to trace element determinations in soil, and in different substrates. Nevertheless, by this technique it is not possible to determine the structural position, kind of coordination and the oxidative state of the elements in these substrates (Filby, 1995).

The present work reports an elemental chemical composition determined in S. auriculata and samples of Ouro Preto city public water supply using neutron activation analysis through the $k_{0}$-standardization method (De corte et al., 1987). The purpose of this study is to investigate the metal bioaccumulation in S. auriculata (Salvinaceae) and to detect the metal occurrence in public water of a specific place.

\section{Experimental}

\subsection{Water and plant sample collection}

S. auriculata was collected in the Pantanal wetland of Campo Grande, Mato Grosso do Sul state, Brazil. The specimens were adapted and grown in natural water obtained from a natural well located in Cel. Quintiliano street $\left(19.48^{\prime} 51^{\prime \prime} \mathrm{S}, 43.40^{\prime} 28^{\prime \prime} \mathrm{W}\right)$ at Ouro Preto city, MG, Brazil. Samples of this water were separated for its use as plant growth medium and also directly collected into a polyethylene flask to be further submitted to INAA (Fig. 1).

\subsection{Analytical procedure}

Sample and standards: Approximately $250 \mathrm{mg}$ of dried and ground $S$. auriculata samples were weighed and stored in a high-density polyethylene flask. Samples of dried $S$. auriculata were first ground in a corindon mortar. Two standard reference materials (SRMs) were simultaneously analyzed to assess the traceability of the results. Samples of water $(15.0 \mathrm{~mL})$ were directly collected from a natural mine stored in a polyethylene flask and submitted to a freeze drying process and the residue obtained was submitted to INAA (Fig. 1).

Irradiations: The irradiation of samples in the polyethylene flask was carried out on a TRIGA MARK-I IPRR1 nuclear reactor at the Centro de Desenvolvimento da Tecnologia Nuclear-Comissão Nacional de Energia Nuclear (CDTN-CNEN), Brazil. Samples and SRM were irradiated at $100 \mathrm{~kW}$, under thermal neutron flux of $6.6 \times 10^{11} \mathrm{n} \mathrm{cm}^{2} \mathrm{~s}^{-1}$ for $10 \mathrm{~h}$.

Counting conditions: Two counting sequences were carried out. (1) After 1 week of cooling, the first count for $300 \mathrm{~s}$ allowed the determinations of ${ }^{140} \mathrm{La},{ }^{82} \mathrm{Br}$ and ${ }^{199} \mathrm{Au}$ and (2) after 1 month of cooling, samples were submitted for the other count for $3.0 \times 10^{4} \mathrm{~s}$ to determine the presence of ${ }^{46} \mathrm{Sc},{ }^{52} \mathrm{Cr},{ }^{59} \mathrm{Fe},{ }^{60} \mathrm{Co},{ }^{65} \mathrm{Zn},{ }^{86} \mathrm{Rb},{ }^{124} \mathrm{Sb}$, ${ }^{144} \mathrm{Ce}$ and ${ }^{233} \mathrm{~Pa}$. The counting system acquisition was constituted by a Canberra hyperpure germanium detector with a full-width at half-maximum (FWHM) resolution of $1.75 \mathrm{keV}$ at $1332 \mathrm{keV}$, with $15 \%$ relative efficiency. All counts were performed at constant geometry in a position where the analyzer deadtime indicator registered less than $5 \%$. The software Genie-2000 was used for spectra processing and peak area determinations.

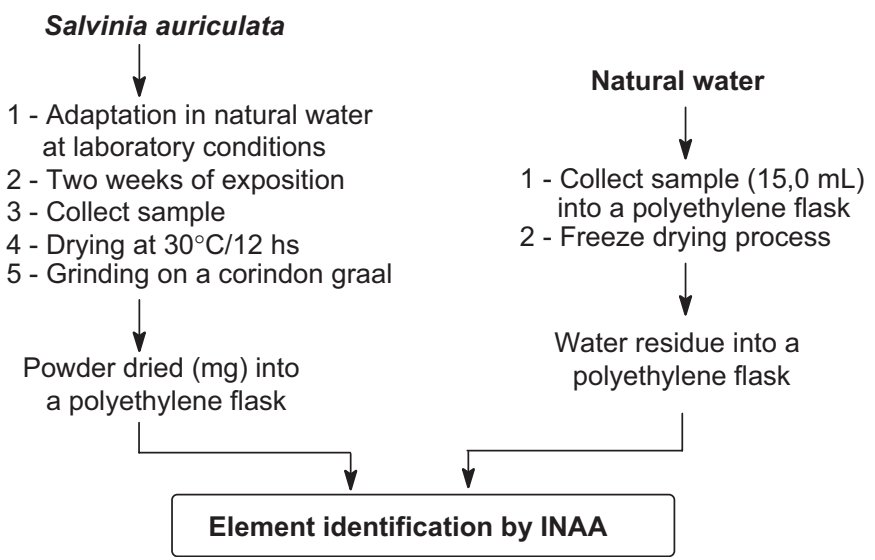

Fig. 1. Scheme of S. auriculata and water sample preparation for INAA 
Table 1

Experimental data of INAA obtained for two GBW (hair, bush and leaves) certified reference materials compared with its standard values

\begin{tabular}{|c|c|c|c|c|}
\hline \multirow[t]{3}{*}{ Element } & \multicolumn{4}{|c|}{$\begin{array}{l}\text { Concentration in reference material }\left(\left(\mu \mathrm{gg}^{-1}\right)\right. \\
\text { (average } \pm \text { standard deviation }))\end{array}$} \\
\hline & \multicolumn{2}{|l|}{ GBW07602 } & \multicolumn{2}{|l|}{ GBW07603 } \\
\hline & Experimental & Standard & Experimental & Standard \\
\hline $\mathrm{Ce}$ & $2.88 \pm 0.4$ & $2.4 \pm 0.2$ & $2.55 \pm 0.4$ & $2.2 \pm 0.1$ \\
\hline Th & $0.41 \pm 0.02$ & $0.37 \pm 0.02$ & $0.37 \pm 0.02$ & $0.36 \pm 0.03$ \\
\hline $\mathrm{Cr}$ & $2.58 \pm 0.3$ & $2.3 \pm 0.2$ & $2.96 \pm 0.4$ & $2.6 \pm 0.1$ \\
\hline $\mathrm{Hf}$ & $0.10 \pm 0.06$ & $0.14 \pm 0.03$ & $0.11 \pm 0.05$ & 0.15 \\
\hline $\mathrm{Sb}$ & $0.031 \pm 0.021$ & $0.078 \pm 0.015$ & $0.065 \pm 0.018$ & $0.095 \pm 0.011$ \\
\hline $\mathrm{Sc}$ & $0.32 \pm 0.08$ & $0.31 \pm 0.02$ & $0.33 \pm 0.07$ & $0.32 \pm 0.02$ \\
\hline $\mathrm{Rb}$ & nd & $4.2 \pm 0.2$ & nd & $4.5 \pm 0.2$ \\
\hline $\mathrm{Fe}$ & $1030 \pm 51$ & $1020 \pm 40$ & $1107 \pm 47$ & $1070 \pm 40$ \\
\hline $\mathrm{Zn}$ & $34.84 \pm 0.9$ & $20.6 \pm 1$ & $57 \pm 2$ & $55 \pm 2$ \\
\hline $\mathrm{Co}$ & $0.46 \pm 0.09$ & $0.39 \pm 0.03$ & $0.48 \pm 0.08$ & $0.41 \pm 0.03$ \\
\hline $\mathrm{La}$ & $1.26 \pm 0.12$ & $1.23 \pm 0.07$ & $1.21 \pm 0.10$ & $1.25 \pm 0.04$ \\
\hline $\mathrm{Br}$ & nd & $2.4 \pm 0.3$ & nd & $3.0 \pm 0.3$ \\
\hline
\end{tabular}

nd $=$ not detected

Table 2

Elements detected by INAA in Salvinia auriculata and samples of Ouro Preto public water supply

\begin{tabular}{lcl}
\hline Element & \multicolumn{2}{c}{ Concentration $\left(\left(\mathrm{gg} \mathrm{g}^{-1}\right)(\right.$ average \pm standard deviation $\left.)\right)$} \\
\cline { 2 - 3 } & Salvinia auriculata & Ouro Preto public water \\
\hline $\mathrm{Ce}$ & $0.920 \pm 0.014$ & nd \\
$\mathrm{Th}$ & $0.095 \pm 0.007$ & $0.006 \pm 0.0014$ \\
$\mathrm{Cr}$ & $1.280 \pm 0.028$ & $0.009 \pm 0.0001$ \\
$\mathrm{Hf}$ & $0.100 \pm 0.08$ & nd \\
$\mathrm{Sb}$ & $0.100 \pm 0.02$ & $0.005 \pm 0.0001$ \\
$\mathrm{Sc}$ & $0.010 \pm 0.0004$ & nd \\
$\mathrm{Rb}$ & $6.500 \pm 0.4$ & $1.18 \pm 0.02$ \\
$\mathrm{Fe}$ & $85.500 \pm 2.120$ & $22.5 \pm 2.1$ \\
$\mathrm{Zn}$ & $4.650 \pm 0.071$ & $1,99 \pm 0.1$ \\
$\mathrm{Co}$ & $0.080 \pm 0.009$ & nd \\
$\mathrm{Au}$ & $0.080 \pm 0.014$ & nd \\
$\mathrm{La}$ & $0.130 \pm 0.014$ & nd \\
$\mathrm{Br}$ & $1.200 \pm 0.08$ & nd \\
\hline
\end{tabular}

nd $=$ not detected.

INAA performance: The resultant sensibility and precision were validated using the following certified SRMs: GBW07602 and GBW07603 materials (human hair, bush and leaves), standards of National Research Center for CRM (GBW).

The analytical procedures with water, SRMs and plant samples were performed monthly in duplicate during a year. The median of the results and respective standard deviations were listed in Tables 1 and 2. Sodium, potassium and iron only were detected by INAA in an empty polyethylene flask in extremely low concentrations that did not interfere in sample analysis. For this reason it was also adopted as a referential blank.

\section{Results and discussion}

The experimental data obtained for the certified SRMs were compared with the respective reference values (Table 1). The elements $\mathrm{Ce}, \mathrm{Th}, \mathrm{Cr}, \mathrm{Hf}, \mathrm{Sb}, \mathrm{Sc}, \mathrm{Rb}, \mathrm{Fe}$, $\mathrm{Zn}, \mathrm{Co}, \mathrm{Au}, \mathrm{La}$ and $\mathrm{Br}$ were detected and quantified in $S$. auriculata. However, some of these elements were only encountered in very low concentrations in the water (Table 2) used for S. auriculata growth.

The peak areas associated with hafnium $\left({ }^{181} \mathrm{Hf}\right.$ : $482.00 \mathrm{keV}$, intensity gamma $(I \gamma): 80.60 \%, T 1 / 2: 42.39$ days), cobalt $\left({ }^{60} \mathrm{Co}: 1173.23 \mathrm{keV}, \quad I \gamma: 99.85 \%\right.$, and $1332.49 \mathrm{keV}, \quad I \gamma: 99,98 \%, T 1 / 2: 5.27$ years), Cerium $\left({ }^{141} \mathrm{Ce}: 145.44 \mathrm{keV}, I \gamma: 48.60 \%, T 1 / 2: 32.50\right.$ days), bromine $\left({ }^{82} \mathrm{Br}: 554.35 \mathrm{keV}, I \gamma: 70.80 \%, T 1 / 2: 35.30 \mathrm{~h}\right)$, Aurum $\left({ }^{198} \mathrm{Au}: 411.80 \mathrm{keV}, I \gamma: 95.00 \%, T 1 / 2: 2.69\right.$ days), lanthanum $\left({ }^{140} \mathrm{La}: 328.76 \mathrm{keV}, I \gamma: 20.30 \%, T 1 / 2: 1.67\right.$ days $)$ and scandium $\left({ }^{46} \mathrm{Sc}: 1120.51 \mathrm{keV}, I \gamma: 100.00 \%, T 1 / 2: 83.83\right.$ days) (Blaauw, 1995) were not registered by software Genie-2000. Therefore, it is possible to conclude that these elements are found below the limit detection level of the technique (Table 2).

The area of rubidium $\left({ }^{86} \mathrm{Rb}: 1076.69 \mathrm{keV}, I \gamma: 8.77 \%\right.$, $T 1 / 2$ : 18.66 days) (Blaauw, 1995) was recorded even considering its low $\gamma$-ray intensity. Nevertheless, although antimonium $\left({ }^{124} \mathrm{Sb} ; 602.73 \mathrm{keV}, I \gamma: 97.70 \%, T 1 / 2: 60.2\right.$ days and ${ }^{125} \mathrm{Sb}: 427.88 \mathrm{keV}, I \gamma: 29.30 \% T 1 / 2: 2.73$ years) (Blaauw, 1995) have high $\gamma$-ray intensity it was only encountered in low concentration (Table 2). These facts show that the non-determination is related to the low element concentration in the sample and not to some difficulty associated with the analysis of the $\gamma$-spectrum.

High chromium concentration was detected in this aquatic plant. Chromium is naturally found in the environment, occurring in soils, rocks and living organisms. It exists in different valence states mainly in the trivalent $[\mathrm{Cr}(\mathrm{III})]$ and hexavalent $[\mathrm{Cr}(\mathrm{VI})]$ forms (Cood et al., 2001). The biological effects associated with chromium uptake are diverse and depend on its oxidation state. The chromium state is non-carcinogenic because of its inability to bind with carriers encountered in cell membranes. On the other hand, exposure to $\mathrm{Cr}(\mathrm{VI})$ is associated with induced gene mutations as well as with incremental risk of lung cancer (Chen and Thilly, 1994; Yang et al., 1992). The carcinogenicity of $\mathrm{Cr}(\mathrm{VI})$ has been extensively explained through many reviews and papers (Bianchi and Levis, 1988; De Flora, 2000; De Flora et al., 1990; Singh et al., 1998; Snow, 1992). Due to chromium VI carcinogenicity, values above $0.05 \mu \mathrm{g} \mathrm{g}^{-1}$ represent a health damage factor (Hayes, 1997; Wetterhahn and Hamilton, 1989). Although, INAA does not indicate the state of oxidation of metals, the quantity encountered in the Ouro Preto water that was tested (Table 2) was about six times lower than the carcinogenic chromium(VI) value.

The results obtained in this work show the high capacity of $S$. auriculata to absorb and accumulate different elements from an untreated water supply, which is 
commonly used by the people of a part of Ouro Preto city . The plant is adequate for use for the uptake, concentration and removal of elements from water.

\section{Conclusion}

The results demonstrate the capacity of $S$. auriculata to absorb and accumulate elements encountered in very low water concentrations, which are not detected by the usual analytical techniques. The elements uptake capacity presented by $S$. ariculata opens up perspectives for its use in aquatic regeneration processes of effluents from mining and other industrial activities, and also to monitor the element concentration in the aquatic environment.

INAA was revealed as an excellent method for this kind of study which was confirmed through the results obtained using certified SRMs.

\section{Acknowledgements}

The authors thank the Comissão Nacional de Energia Nuclear (CNEN) for financial support and Dra. Maria Ângela de Barros Correa Menezes (CNEN/CDTN) for her help during the INAA procedures.

\section{References}

Bianchi, V., Levis, A.G., 1988. Review of genetic effects and mechanisms of action of chromium compounds. Sci. Total Environ. 71, 351-355.

Blaauw, M., 1995. The IRI Gamma-ray Catalogue for INAA. Interfaculty Reactor Institute, University of Technology Delft, Delft, The Netherlands.

Callender, E., Rice, K.C., 2000. The urban environmental gradient: anthropogenic influences on the spatial and temporal distributions of lead and zinc in sediments. Environ. Sci. Technol. 34 (2), 232-238.

Chen, J., Thilly, W.G., 1994. Use of denaturing-gradient gel electrophoresis to study chromium-induced point mutations in human cells. Environ. Health Perspect. 102, 227-229.

Cood, R., Dillon, C.T., Levina, A., Lay, P.A., 2001. Studies on the genotoxicity of chromium: from the test tube to the cell. Coord. Chem. Rev. 216, 537-582.

De Corte, F., Simonits, A., De Wispelaere, A., Hoste, J., 1987. Accuracy and applicability of the $\mathrm{K}_{0}$-standardization method. J. Radioanal. Nucl. Chem. 113, 145-161.

De Flora, S., 2000. Threshold mechanisms and site specificity in chromium(VI) carcinogenesis. Carcinogenesis 2, 533-541.

De Flora, S., Bagnasco, M., Serra, D., Zanacchi, P., 1990. Genotoxicity of chromium compounds: a review. Mutat. Res. 238, 99-172.
Eccles, H., 1999. Treatment of metal-contaminated wastes: why select a biological process? Trends Biotechnol. 17, 462-465.

Filby, R.H., 1995. Isotopic and nuclear analytical techniques in biological systems: a critical study. Part IX. Neutron activation analysis technical report. Pure Appl. Chem. 67, 1929-1941.

Forno, I.W., Harley, K.L.S., 1979. The occurrence of Salvinia molesta in Brazil. Aquat. Bot. 6, 185-187.

Garg, P., Chandra, P., 1990. Toxicity and accumulation of chromium in Ceratophylum demersum L. Bull. Environ. Contam. Toxicol. 44, 473-478.

Hayes, R.B., 1997. The carcinogenicity of metals in humans. Cancer Cause Control 8, 371-385.

International Atomic Energy Agency, 2001 (TECDOC 1215). Use of Research Reactors for Neutron Activation Analysis. Vienna.

Klumpp, A., Bauer, K., Franz-Gerstein, C., Menezes, M., 2002. Variation of nutrient and metal concentrations in aquatic macrophytes along the Rio Cachoeira in Bahia (Brazil). Environ. Int. 28, 117-165.

Larcher, W., 2000. Ecofisiologia vegetal. Ed. Rima Artes e Textos. São Carlos, Sâo Paulo, 531pp.

Litchfield, C., 2005. Thirty years and counting: bioremediation in its prime? Bioscience 55, 273-279.

Pardeshi, B.M., Rajurkar, N.S., 1997. Analysis of some herbal plants from India used in the control of Diabetes mellitus by NAA and AAS techniques. Appl. Radiat. Isot. 48, 1059-1062.

Saiki, M., Chaparro, C.G., Vasconcellos, M.B.A., Marcelli, M.P., 1997. Determination of trace elements in lichens by instrumental neutron activation analysis. J. Radioanal. Nucl. Chem. 217, 111-115.

Schneider, I.A.H., Rubio, J., 1999. Sorption of heavy metals ions by the non-living biomass of freshwater macrophytes. Environ. Sci. Technol. $33,2213-2217$.

Singh, J., Carlisle, D.L., Pritchard, D.E., Patierno, S.R., 1998. Chromiuminduced genotoxicity and apoptosis: relationship to chromium carcinogenesis. Oncol. Rep. 5, 1307-1318.

Snow, E.T., 1992. Metal carcinogenesis: mechanistic implications. Pharmacol. Ther. 53, 31-65.

Srivastav, R.K., Gupta, S.K., Nigan, K.D.P., Vasudevan, P., 1994. Treatment of chromium and nickel in wastewater by using aquatic plant. Water Res. 28, 1631-1638.

Stolze, R.G., Ollgaard, B., Hickey, R.J., 1983. Ferns and Fern Allies of Guatemala, Part III. Marsileaceae, Salviniaceae, and the Fern Allies (including a comprehensive index to Parts I, II and III), vol. 12, 91pp., and 10 illustrations.

Vaz, S.M., Saiki, M., Vasconcelos, M.B.A., Sertié, J.A.A., 1995. Neutron activation analysis of medicinal plant extracts. J. Radioanal. Chem. 195, 185-193.

Wetterhahn, K.E., Hamilton, J.W., 1989. Molecular basis of hexavalent chromium carcinogenicity: effect on gene expression. Sci. Total Environ. 86, 113-115.

Yang, J.L., Hsieh, Y.C., Wu, C.W., Lee, T.C., 1992. Mutational specificity of chromium(VI) compounds in the hprt locus of Chinese hamster ovary-K1 cells. Carcinogenesis 13, 2053-2057. 